\title{
Sistem Opinion Mining dengan Metode Pos Tagging dan SVM Untuk Ekstraksi Data Opini Publik pada Layanan JKBM
}

\author{
Luh Ria Atmarani ${ }^{1}$, I.A. Dwi Giriantari ${ }^{2}$, Made Sudarma ${ }^{3}$
}

\begin{abstract}
Sentiment analysis can be used to extract the opinions of lines of text into an information line. One method used is the Hidden Markov Model. HMM is used to provide word class grammatically the sentence. After determining the word class then apply the rule based. By using a rule based the sentence can be specified include opinions or not. Support Vector Machine method is used to classify the opinions in positive or negative opinion. Data used is data on complaints handling and on-line opinion Technical Services Unit Bali Mandara Health Insurance Bali Province. Results of opinion mining process will be tested using the method precission, recall and accuracy. The results show the percentage of the value of precission, recall and accuracy have an average percentage of 89 percent. It shows the method of tagging posts and SVM were able to classify sentences into the opinions
\end{abstract}

Intisari- Analisis sentiment digunakan untuk mengekstrak opini dari baris baris teks menjadi suatu informasi. Metode yang digunakan adalah Hidden Markov Model (HMM). HMM digunakan untuk memberikan kelas kata secara gramatikal pada suatu kalimat. Penentuan aturan kalimat opini dengan menggunakan rule based. Metode Support Vector Machine digunakan untuk membagi opini menjadi opini positif atau negatif. Hasil proses opinion miningakan diuji menggunakan metode precission, recall dan akurasi. Hasil penelitian menunjukkan presentase nilai precission, recall dan akurasi memiliki rata rata presentase sebesar 89 persen. Ini menunjukkan metode pos tagging dan SVM mampu mengklasifikasikan kalimat kedalam opini dan menentukan kalimat ke dalam opini positif dan negatif.

Kata Kunci-Opinion Mining, Hidden Markov Model, Rule Based, Support Vector Machine, Precission, Recall, Akurasi.

\section{PENDAHULUAN}

Jaminan Kesehatan Bali Mandara (JKBM) merupakan program asuransi kesehatan dalam bidang pelayanan kesehatan JKBM ditujukan untuk masyarakat Bali yang belum memiliki Jaminan Kesehatan. Unit Pelaksana Teknis Jaminan kesehatan Masyarakat Bali (UPT JKMB) adalah pengelola program JKBM. Data Perjanjian Kerja Sama (PKS) tahun 2014 menyatakan JKBM memiliki jumlah peserta 2.733 .414 peserta

${ }^{1}$ Staff UPT JKMB Dinas Kesehatan Provinsi Bali, Mahasiswa Magister Teknik Elektro Bidang Studi Manajemen Sistem Informasi dan Komputer Universitas Udayana, Kampus Sudirman Denpasar Bali (telp.0361-239599; fax:0361-239599; email: ria.atmarani@gmail.com)

${ }^{2}$ Dosen Magister Teknik Elektro dan Komputer Universitas Udayana, Kampus Sudirman, Denpasar Bali, (Telp. 0361-239599, fax: 0361-239599;email:dayu.giriantari@unud.ac.id)

${ }^{3}$ Dosen Magister Teknik Elektro dan Komputer Universitas Udayana, Kampus Sudirman, Denpasar Bali, (Telp. 0361-239599, fax: 0361-239599; email:Msudarmai@unud.ac.id)

Luh Ria Atmarani: Sistem Opinion Mining dengan ... yang tersebar di seluruh Bali.Pada tanggal 15 April 2013 JKBM menanggung kecelakaan tunggal, cacat bawaan seperti penderita hidrocepalus, bayi tanpa anus, dan bayi tanpa saluran kencing. Dan yang terbaru sesuai Edaran Gubernur, JKBM menanggung persalinan per 1 Januari 2014[1].Selama berlangsung dari tahun 2010 beragam opini muncul dari masyarakat tentang pelayanan JKBM, baik pada simakrama Gubernur Bali, sosialisasi JKBM ke Kabupaten/Kota, sosialisasi pada petugas kesehatan atau pada media cetak maupun media elektronik.

Opini yang muncul dari masyarakat merupakan hal yang penting pada sebuah instansi pelayanan publik. Selama ini, opini yang muncul tentang pelayanan JKBM tidak pernah ditampung dan dianalisis sentimennya, apakah opini pelayanan JKBM berorientasi positif atau negatif.. Selama ini ribuan data yang ada pada bagian penanganan keluhan tidak pernah dikelola dengan baik. Analisis sentimen atau opinion mining adalah pengolahan bahasa alami untuk melacak sikap, perasaan atau penilaian dari masyarakat tentang topik tertentu, produk atau jasa [2]. Data opini dapat mengungkap hal hal yang belum terungkap pada pelayanan JKBM. Penelitian ini untuk melakukan penerapan metode opinion mining untuk menganalisis data opini masyarakat baik peserta JKBM maupun non peserta sehingga opini itu dapat dimanfaatkan untuk membantu bagian penanganan keluhan dalam menganalisis data opini peserta JKBM.

Penggunaan opinion mining digunakan untuk mengekstrak pendapat dari teks dan menjadi suatu informasi. Ini adalah bahan studi yang banyak dikaji, dan tidak diragukan lagi nilai komersialnya [3]. Karena banyaknya informasi (perkiraan umum diatas $80 \%$ ) disimpan sebagai teks, dan opinion mining diyakini mempunyai potensi nilai komersial tinggi [4]. Metode Support Vector Machine atau SVM bisa digunakan untuk menggolongkan opini ke dalam opini positif dan negatif. Sedangkan dari natural language processing metode yang dapat digunakan untuk menyelesaikan masalah pada Opinion Mining yaitu Part of Speech (POS) tagging. Pos Tagging digunakan untuk memberi kelas kata secara gramatikal pada tiap kata dalam kalimat. Pos Tagging menggunakan Hidden Makov Model (HMM). HMM merupakan model statistik pada sistem yang melakukan perhitungan probabilitas pada satu kejadian yang tidak bisa diamati berdasarkan kejadian yang bisa diamati [5]. Pada hasil POS taggingakan diberikan aturan untuk mengetahui suatu dokumen termasuk opini atau bukan, dan membandingkan bagian kalimat yang merupakan obyek yang menjadi target opini. Kalimat yang dibaca opini kemudian diklasifikasikan menjadi opini negatif dan positif menggunakan SVM.

Penelitian - penelitian terkait metode untuk opinion mining dan pos tagging telah banyak dilakukan antara lain Kathryn Widiyanti melakukan penelitian menggunakan pelabelan kelas p-ISSN:1693 - 2951; e-ISSN: 2503-2372 
kata teks berbahasa Indonesia. Dalam penelitian ini Pos Tagging menggunakan metode Hidden Markov Model dan Ruled Based untuk menentukan suatu kalimat opini atau bukan. Pravesh Kumar dan Mohid Shahid, melakukan perbandingan metode menggunakan $\mathrm{N}-\mathrm{Gram}$ Feature, Naive Bayes, MCD dan SVM pada opinion mining untuk movie reviews dan product reviews. Dan SVM memiliki tingkat akurasi lebih baik diantara metode lainnya. Law, et al dalam penelitiannya yang berjudul Sentiment Classification Of Online Reviews To Travel Destinations By Supervised Machine Learning Approaches, membandingkan metode naive bayes, $N$-gram dan SVM classifier. Pada penelitian ini didapatkan akurasi SVM lebih baik dari metode klasifikasi lainnya.

Melihat permasalahan yang ada, pada penelitian ini akan dibangun suatu aplikasi yang untuk ekstraksi data opini publik pada JKBM. Metode yang akan digunakan dalam melakukan analisis opini adalah SVM untuk klasifikasi opini dan penentuan Pos Taggingdengan HMM dan Rule Based sehingga diharapkan memperoleh klasifikasi data opini yang lebih akurat untuk mengetahui sentimen publik pada layanan JKBM.

\section{Metode}

\section{A. Hidden Markov Model}

Hidden Markov Modeldikembangkan dari Markov Chain yaitu keadaan yang akan datang dari suatu sequence tidak ditentukan dari keadaan saat ini, tapi juga perpindahan dari suatu state ke state sequence yang lain. State sequence inilah adalah bagian hidden dari suatu hidden markov models[6]. PadaPOS Tagging, data yang diamatiadalah kumpulan kata, dari kumpulan kata akan ditentukan tiap kata yang masuk dalam kelas kata yang tepat. Sebagai gambaran proses HMM, satu kalimat tersebut akan diberikanalur tag yang paling sesuai[7]. Rumus ditunjukan pada persamaan (1). Persamaan dibawah adalah persamaan dari Hidden Markov Model pada kasus Part of Speech Tagging

$\operatorname{Tag}_{n}=\operatorname{Max}\left(P\left(\right.\right.$ orord $\left.\left._{i} \mid \operatorname{tag}_{i}\right) * P\left(\operatorname{tag}_{i} \mid \operatorname{tag}_{i}-1\right)\right)$

Pada HMM POS Taggerasumsi probabilitas suatu kemunculantag menggunakan bigram yang mana probabilitas kemunculan hanya bergantung dari tag sebelumnya, dan akan ditunjukkan pada persamaan (2)

$$
\begin{aligned}
& t_{1-n}=\arg \max t_{1} \ldots t_{n} P\left(t_{1}\right) * \prod_{i=2}^{n} P\left(t_{i} \mid t_{i-1}\right) * \\
& \prod_{i=1}^{n} P\left(w_{i} \mid t_{i}\right)(2)
\end{aligned}
$$

\section{B. Rule Based}

Rule Based ini merupakan metode yang menggunakan aturan bahasa (grammar) untuk mendapatkan kelas kata pada suatu kata dalam suatu kalimat. Metode Rule Base ini memiliki 2 arsitektur. Metode yang pertama adalah metode Rule base yang menggunakan kamus untuk menandai kata dengan kelas kata (leksikon)[8]. Pada penelitian ini proses rule based diawali dengan memproses hasil dari Hidden Markov Model yang berupa kata berikut kelas katanya akan dipecah menjadi kalimat-kalimat dengan parameter titik, koma, tanda tanya dan tanda seru. Setelah itu kata akan diambil kelas katanya. Kemudian dari kelas kata pertama sampai terakhir akandicocokan dengan rule yang sudah ada dikamus aturan. Jika semua susunan aturanpada kalimat ada pada kamus aturan, maka sistem menampilkan kata dengan kelas katanya sebagai output. Jika ada perbedaan kelas kata dengan kelas kata pada kamus, maka sistem memberi tanda pada kata pada hasil HMM

\section{Support Vector Machine (SVM)}

SVM adalah proses pembelajaran terbimbing dan menganalisa suatu data sertaproses pengenalan pola, digunakan metode ini biasanya digunakan pada klasifikasi dan analisis regresi. SVM yang standar memperoleh data dan memprediksi setiap masukanyang diberikan, kemungkinan masukan adalah anggota pada salah satu kelas dari dua kelas yang ada, yang menjadikan SVM sebagai penggolong non probabilistik linier biner[9]. SVM sebagai pengklasifikasi akan diberi data latih, masing-masing diberi tanda sebagai milik salah satu dari dua kategori, algoritma pelatihan SVM membangun sebuah model yang memprediksi apakah data yang baru jatuh ke dalam suatu kategori atau yang lain. Hyperlane pemisah terbaik antara kedua kelas diperoleh dengan mengukur margin dari hyperlane serta mencari margin terbesar. Margin adalah jarak antara hyperlane tersebut dengan data terdekat dari masing masing kelas[10]. Usaha mencari lokasi hyperlaneadalah inti dari proses pembelajaran pada SVM. Ada banyak hyperplane yang mengklasifikasikan data. Hyperplaneyang paling baik yaitu satu garis yang mewakili pemisahan atau margin terbesar, antara dua kelas. Kita memilih hyperplane yang jarak dari dan ke titik data terdekat di setiap sisi dimaksimalkan. Jika sebuah garis maksimal ditemukan, maka dikenal sebagai hyperplane maksimum margin dan linier classifier yang didefinisikannya dikenal sebagai pengklasifikasi margin maksimal[11]. Gambar1 menunjukkan hyperlane margin

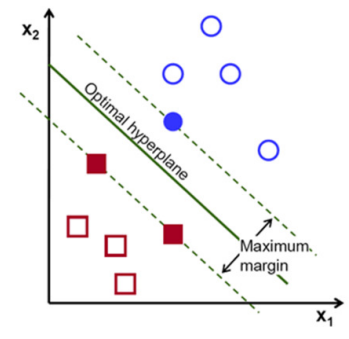

Gambar 1: Hyperlane Margin Maximal

$\vec{w} \cdot \vec{x}+b=0$

Pola (x_i ) yang merupakan kelas -1 (sample negatif) akan dirumuskan menjadi pattern dan memenuhi pertidaksamaan

$\vec{w} \cdot \overrightarrow{w x}+b \leq-1$

Untuk pola (x_i ) yang termasuk kelas +1 (sample positif)

$\vec{w} \cdot \overrightarrow{w x}+b \geq+1$

\section{GAMBARAN UMUM SISTEM}

Gambaran umum sistem dari penelitian inidapat digambarkan dengan Block Diagram. Block Diagram menggambarkan alur sistem secara umum yang berupa masukan, proses dan keluaran dari sistem. Secara keseluruhan gambaran umum dari system pada penelitian ini dapat dilihat pada gambar berikut. 


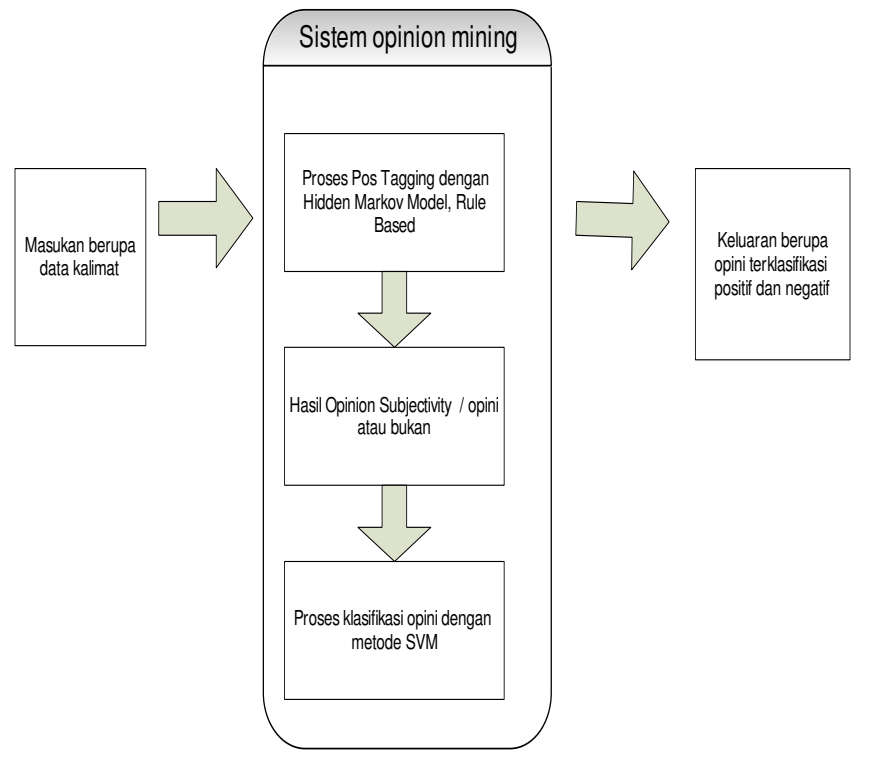

Gambar 2: Gambaran Umum Sistem

\section{ALUR PENELITIAN}

Diagram alur penelitian dapat dilihat pada gambar 3 . Langkah - langkah proses pda alur penelitian adalah sebagai berikut :

1. Proses dimulai dengan pengumpulan data. Data diperoleh dari data penangan keluhan dan kuesioner online tentang pendapat masyarakat seputar JKBM.

2. Proses dilanjutkan dengan pengambilan data dan akan dilakukan pemecahan kata atau tokenisasi. Kemudian tiap kata akan diperoleh probabilitasnya menggunakan HMM. Proses HMM melibatkan proseshidden state dan observed state. Setelah diperoleh hasil dari HMM, maka hasil tersebut akan diproses dengan Rule Based agar dapat diklasifikasi ke dalam data opini atau bukan dengan kamus aturan sehingga memperoleh data berupa document subjectivity.35 Tagset Bahasa Indonesia digunakan pada proses Pos Tagging dengan mengacu pada KBBI Kateglo. Contoh Tagset yaituNN (Common Noun) contohnya Mobil, PRP(Personal Pronouns) contohnya Saya, Kamu, VBI(Intransitive Verb) contohnya Pergi, VBT(Transitive Verb) contohnya Membeli, JJ(Adjective) contohnya kecewa, dan $\mathrm{RB}($ Adverb $)$ contohnya Sementara, Nanti
Gambar 3: Gambaran Alur Penelitian

3. Pada klasifikasi dengan svm dimulai dengan mengubah kalimat yang terklasifikasi opini menjadi data vektor. Data vector memiliki 2 komponen yaitu dimensi dan bobot, yang mana bobot sering dituangkan dalam nilai tf-idf, tfidf adalah nilai bobot kata berdasarkan perhitungan tfidf. Kemudian proses dilanjutkan dengan pemberian skor dimana jika diatas 0 data termasuk dalam kelas positif dan dibawah 0 termasuk kelas negating. Data tersebut nantinya merupakan opini terklasifikasi positif atau negatif. Prose ditunjukkan pada gambar dibawah ini.

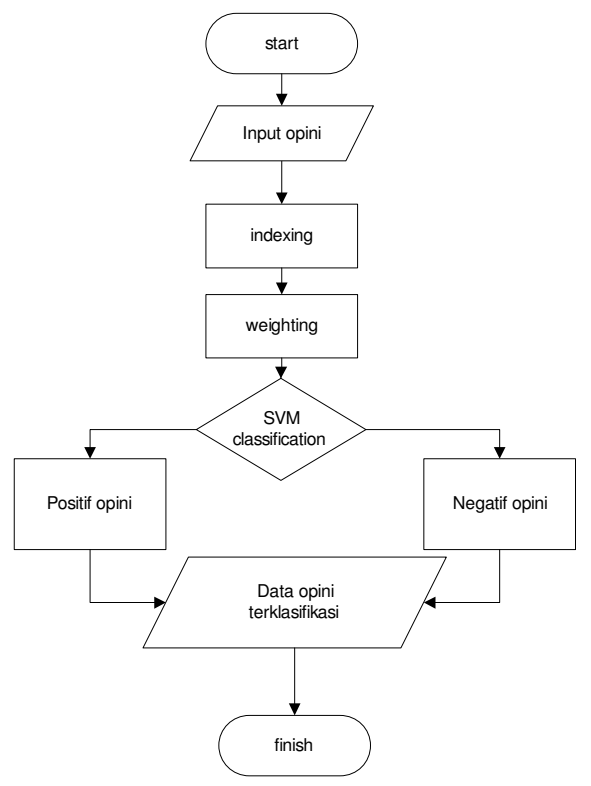

Gambar 4:Diagram Proses SVM 
4. Proses pengujian sistem dengan membandingkan hasil opinion classification pada data uji dengan metode perhitungan precission, recall dan akurasi.

\section{TAMPILAN SISTEM}

Tampilan sistem berfungsi untuk memudahkan user memasukkan kalimat dan melihat proses yang dilakukan serta hasil dari tahapan penelitian. Berikut adalah antar muka dari halaman input kalimat

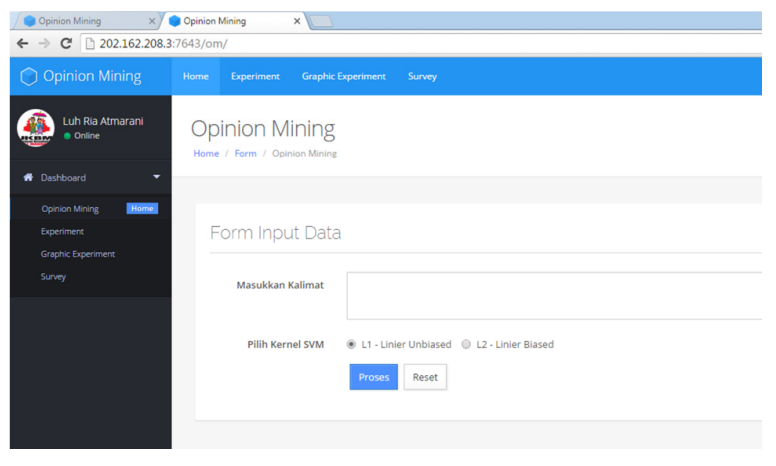

Gambar 5: tampilan input kalimat

Kalimat kemudian diproses dengan pos tagging. Setelah diperoleh hasil, kemudian data tersebut diproses menggunakan rule based untuk menentukan kalimat tersebut opini atau bukan. Setelah itu data opini akan dirubah kedalam bentuk vector yang kemudian akan diklasifikasi dengan menggunakan support vector machine. Tampilan hasil proses proses pos tangging dengan Hidden Markov Model dan Rule Based serta klasifikasi menggunakan Support Vector Machine dapat dilihat pada gambar berikut.

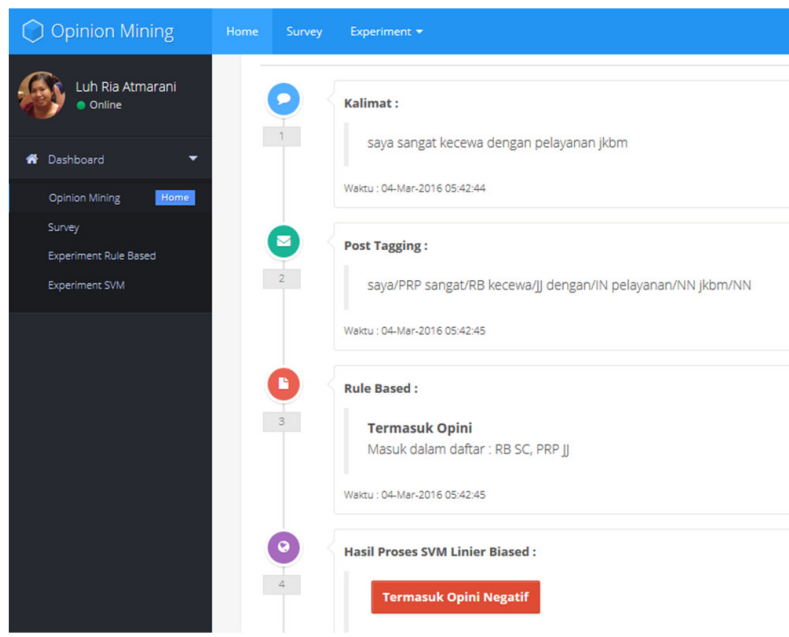

Gambar 6: tampilan proses pos tagging

Pada gambar 6 talimat diinputkan pada kolom masukkan kalimat dan kernel SVM yang dipilih adalah SVM Linier Unbiased dengan kalimat input "Saya sangat kecewa dengan pelayanan JKBM". Hasil Pos Tagging yaitu Saya/PRP
sangat/RB kecewa/jj dengan/NN pelayanan/NN $\mathrm{jkmb} / \mathrm{NN}$, pada rule based termasuk opini dan hasil yang ditampilkan adalah opini negatif. Opini negatif dibaca dari data vektor yang muncul di output dengan nilai vektor 0.37119843 . Tanda minus pada nilai tersebut menunjukkan opini terklasifikasi sebagai opini negatif

\section{EKSPERIMEN}

Pengujian data diperoleh dari data penangan keluhan dan data opini online. Data uji terdiri dari 30, 50, 100, 500, 1000, 1500, 2000, 2500, 3000 dan 3300 data uji. Berikut sampel dari data 30 data uji

TABELI

TABEL 30 DATA UJI

\begin{tabular}{|c|c|c|c|}
\hline \multirow[b]{2}{*}{ No } & \multirow[b]{2}{*}{ Kalimat } & \multicolumn{2}{|c|}{ Sentimen } \\
\hline & & $\begin{array}{l}\text { Klasifikasi } \\
\text { Secara } \\
\text { Manual }\end{array}$ & $\begin{array}{l}\text { Klasifik } \\
\text { asi Oleh } \\
\text { Sistem }\end{array}$ \\
\hline 1 & $\begin{array}{l}\text { didesa saya belum dapat kartu } \\
\text { jkbm tolong dicek di desa } \\
\text { duda, tepatnya banjar padang } \\
\text { tunggal. Saya kalau berobat } \\
\text { mesti urus surat keterangan } \\
\text { tidak memiliki jaminan } \\
\text { kesehatan dulu, karena tidak } \\
\text { adanya kartu jkbm }\end{array}$ & $\begin{array}{l}\text { Opini } \\
\text { negatif }\end{array}$ & $\begin{array}{l}\text { Opini } \\
\text { negative }\end{array}$ \\
\hline 2 & $\begin{array}{l}\text { saya punya orangtua punya } \\
\text { kartu jkbm terus dia sakit } \\
\text { jantung kenapa kok terus } \\
\text { dikasi resep untuk beli obat } \\
\text { dan harganya lumayan tinggi } \\
\text { saya merasa heran apa } \\
\text { untungnya kartu jkbm }\end{array}$ & $\begin{array}{l}\text { Opini } \\
\text { negatif }\end{array}$ & $\begin{array}{l}\text { Opini } \\
\text { negatif }\end{array}$ \\
\hline 3 & $\begin{array}{l}\text { tolong obat obatan yang } \\
\text { ditanggung jkbm jangan } \\
\text { sampai kosong dipuskesmas } \\
\text { karena itu yang menyebabkan } \\
\text { adanya pembayaran atas obat } \\
\text { yang tidak ditanggung }\end{array}$ & $\begin{array}{l}\text { Opini } \\
\text { Negatif }\end{array}$ & $\begin{array}{l}\text { Opini } \\
\text { Negatif }\end{array}$ \\
\hline 4 & $\begin{array}{l}\text { Terima kasih JKBM atas } \\
\text { bantuannya selama lima hari } \\
\text { anak kami rawat nginap di } \\
\text { RSUD Buleleng.JKBM } \\
\text { memang sangat bermanfaat } \\
\text { bagi kami. }\end{array}$ & $\begin{array}{l}\text { Opini } \\
\text { positif }\end{array}$ & $\begin{array}{l}\text { Opini } \\
\text { negatif }\end{array}$ \\
\hline 5 & $\begin{array}{l}\text { sistem verifikasi dipuskesmas } \\
\text { dan rumah sakit masih belum } \\
\text { sempurna }\end{array}$ & $\begin{array}{l}\text { Opini } \\
\text { negatif }\end{array}$ & $\begin{array}{l}\text { Opini } \\
\text { negatif }\end{array}$ \\
\hline 6 & $\begin{array}{l}\text { untuk pasien gawat darurat } \\
\text { seharusnya di tolong dahulu } \\
\text { bukan lagi harus mengurus } \\
\text { administrasinya, bagaimana } \\
\text { jika waktu menunggu } \\
\text { administrasi pasien tambah } \\
\text { gawat }\end{array}$ & $\begin{array}{l}\text { Opini } \\
\text { negatif }\end{array}$ & $\begin{array}{l}\text { Opini } \\
\text { negatif }\end{array}$ \\
\hline 7 & $\begin{array}{l}\text { pelaksanaan program jkbm di } \\
\text { RSUD Bangli kurang } \\
\text { medapatkan pelayanan, begitu } \\
\text { pula untuk urusan obat seperti } \\
\text { antibitik ada kesan pasien }\end{array}$ & $\begin{array}{l}\text { Opini } \\
\text { negatif }\end{array}$ & $\begin{array}{l}\text { Opini } \\
\text { negatif }\end{array}$ \\
\hline
\end{tabular}




\begin{tabular}{|c|c|c|c|}
\hline \multirow[b]{2}{*}{ No } & \multirow[b]{2}{*}{ Kalimat } & \multicolumn{2}{|c|}{ Sentimen } \\
\hline & & $\begin{array}{l}\text { Klasifikasi } \\
\text { Secara } \\
\text { Manual }\end{array}$ & $\begin{array}{l}\text { Klasifik } \\
\text { asi Oleh } \\
\text { Sistem }\end{array}$ \\
\hline & $\begin{array}{l}\text { digiring membeli antibiotik } \\
\text { diluar tanggungan jkbm, } \\
\text { mohon diperhatikan }\end{array}$ & & \\
\hline 8 & $\begin{array}{l}\text { mengurus jkbm dikantor desa } \\
\text { sering susah sering sekali } \\
\text { kantor kepala desa dalam } \\
\text { kondisi terkunci seperti di } \\
\text { desa batuagung banjar } \\
\text { batuagung }\end{array}$ & $\begin{array}{l}\text { Opini } \\
\text { negatif }\end{array}$ & $\begin{array}{l}\text { Opini } \\
\text { negatif }\end{array}$ \\
\hline 9 & $\begin{array}{l}\text { banyak masyarakat desa } \\
\text { abiansemal badung yang tidak } \\
\text { memperoleh kartu tetapi ada } \\
\text { juga warga seperti i wayan } \\
\text { yudana yang memperoleh } 3 \\
\text { kartu sekaligus }\end{array}$ & $\begin{array}{l}\text { Opini } \\
\text { negatif }\end{array}$ & $\begin{array}{l}\text { Opini } \\
\text { negatif }\end{array}$ \\
\hline 10 & $\begin{array}{l}\text { pelaksanaan program jkbm di } \\
\text { RSUD Bangli kurang } \\
\text { medapatkan pelayanan, begitu } \\
\text { pula untuk urusan obat seperti } \\
\text { antibitik ada kesan pasien } \\
\text { digiring membeli antibiotik } \\
\text { diluar tanggungan jkbm, } \\
\text { mohon diperhatikan }\end{array}$ & $\begin{array}{l}\text { Opini } \\
\text { negatif }\end{array}$ & $\begin{array}{l}\text { Opini } \\
\text { negatif }\end{array}$ \\
\hline
\end{tabular}

Data pengujian 30 data opini yang digunakan pada Tabel 1 terdiri dari pengujian manual terdiri dari 20 opini negatif dan 10 opini positif. Sedangkan hasil klasifikasi Linier Unbiased yang dilakukan oleh sistem, diperoleh 20 data opini termasuk sentimen negatif dan 8 opini termasuk opini positif, dan 2 opini positif dibaca negatif. Berikut ini adalah Tabel confusion matrix yang digunakan sebagai acuan untuk menghitung nilai precision, recall dan akurasi. Tabel nilai matriks ditunjukkan pada tabel 2

TABEL II

TABEL NilAi CONFUSION MATRIX UnBiASED

\begin{tabular}{|c|c|c|c|}
\hline & \multicolumn{2}{|c|}{ Kelas Prediksi } \\
\hline & & positif & negatif \\
\hline \multirow{2}{*}{$\begin{array}{l}\text { Kelas } \\
\text { Sebenarnya }\end{array}$} & Positif & 8 & 2 \\
\hline & negatif & 0 & 20 \\
\hline
\end{tabular}

Pada SVM, menggunakan SVM linier dengan liner biased dan unbiased. Untuk perhitungan akurasi, Precision dan Recall Linier Unbiased adalah sebagai berikut

TABEL III

TABEL NilAi CONFUSION MATRIX BIASED

\begin{tabular}{|l|l|l|l|}
\hline \multicolumn{2}{|c|}{} & \multicolumn{2}{c|}{ Kelas Prediksi } \\
\cline { 3 - 4 } \multicolumn{2}{|c|}{} & \multicolumn{1}{c|}{ positif } & \multicolumn{1}{c|}{ negatif } \\
\hline $\begin{array}{l}\text { Kelas } \\
\text { Sebenarnya }\end{array}$ & Positif & 10 & 0 \\
\cline { 2 - 4 } & negatif & 0 & 20 \\
\hline
\end{tabular}

Berdasarkan pengujian, didapatkan hasil akurasi Linier Unbiased klasifikasi opini dari sistem opinion mining dengan HMM, rule based dan SVM sebesar 93\% dengan precision sebesar $100 \%$ dan recall sebesar $80 \%$. Sedangkan hasil Linier Luh Ria Atmarani: Sistem Opinion Mining dengan ... biased klasifikasi opini dari sistem opinion mining dengan HMM, rule based dan SVM dengan precision, recall dan akurasi sebesar $100 \%$.

\section{A. Hasil Uji Sistem dengan SVM Linier Unbiased}

Dari proses pengujian data 30 data uji diperoleh nilai precisionsebesar $100 \%$ dan recall sebesar $80 \%$, serta akurasi sejumlah $93 \%$. Pada data 50 data uji diperoleh nilai akurasi sebesar $90 \%$ dengan precision sebesar $96 \%$ dan recall sebesar $85 \%$. Pada 100 data uji diperoleh nilai precision sebesar $100 \%$ dan recall sebesar $80 \%$, sedangkan dari 500 data uji diperoleh nilai precision sebesar $96,15 \%$ dan recall sebesar $98,80 \%$. Untuk data sejumlah 1000 uji diperoleh recall sebesar 95,95\% dan precision sebesar 99,40\%. Berikut Tabel 4 dengan persentase nilai precision dan recall dari masing masing jumlah data uji.

TABELIV

PERSENTASE PRECISION, RECALL, AKURASI LINIER UNBIASED

\begin{tabular}{|l|l|l|l|}
\hline Jumlah data uji & precision & Recall & Akurasi \\
\hline 30 data uji & $100 \%$ & $80 \%$ & $93 \%$ \\
\hline 50 data uji & $96 \%$ & $85 \%$ & $90 \%$ \\
\hline 100 data uji & $96,15 \%$ & $100 \%$ & $98 \%$ \\
\hline 500 data uji & $96,11 \%$ & $98,80 \%$ & $97,40 \%$ \\
\hline 1000 data uji & $95,95 \%$ & $99,40 \%$ & $97,60 \%$ \\
\hline 1500 data uji & $97 \%$ & $99,20 \%$ & $98,07 \%$ \\
\hline 2000 data uji & $96,41 \%$ & $99,40 \%$ & $97,85 \%$ \\
\hline 2500 data uji & $97,25 \%$ & $99,04 \%$ & $98,12 \%$ \\
\hline 3000 data uji & $95,61 \%$ & $98,80 \%$ & $97,13 \%$ \\
\hline 3300 data uji & $96,01 \%$ & $99,00 \%$ & $97,21 \%$ \\
\hline
\end{tabular}

\section{B. Hasil Uji Sistem dengan SVM Linier biased}

Pada pengujian SVM Linier biased, setelah sistem melakukan pengujian dengan jumlah data uji yang berbeda beda maka nilai precision dan recall dan akurasinya ditunjukkan pada tabel 5

TABELV

RSENTASE PRECISION, RECALL, AKURASI LINIER BIASED

\begin{tabular}{|l|l|l|l|}
\hline Jumlah data uji & \multicolumn{1}{|c|}{ precision } & \multicolumn{1}{|c|}{ Recall } & \multicolumn{1}{|c|}{ Akurasi } \\
\hline 30 data uji & $100 \%$ & $100 \%$ & $100 \%$ \\
\hline 50 data uji & $96 \%$ & $93 \%$ & $94 \%$ \\
\hline 100 data uji & $98,04 \%$ & $100 \%$ & $99 \%$ \\
\hline 500 data uji & $96,11 \%$ & $98,80 \%$ & $97,40 \%$ \\
\hline 1000 data uji & $96,13 \%$ & $99,40 \%$ & $97,70 \%$ \\
\hline 1500 data uji & $97,00 \%$ & $99,20 \%$ & $98,07 \%$ \\
\hline 2000 data uji & $96,32 \%$ & $99,40 \%$ & $97,80 \%$ \\
\hline 2500 data uji & $97,02 \%$ & $99,04 \%$ & $98 \%$ \\
\hline 3000 data uji & $97,24 \% \%$ & $98,47 \%$ & $97,83 \%$ \\
\hline 3300 data uji & $97,21 \%$ & $96,01 \%$ & $99 \%$ \\
\hline
\end{tabular}

Dari proses pengujian data dengan Linier Biased data 30 data uji (20 opini negatif dan 10 opini positif) diperoleh nilai precisionsebesar $100 \%$ dan recall sebesar $100 \%$, serta akurasi sejumlah $100 \%$. Pada data 50 data uji (28 opini positif dan 22 opini negatif) diperoleh nilai precision sebesar 90,48\%, recall sebesar 95\% dan akurasi sebesar $94 \%$. Pada 100 data (50 opini positif dan 50 opini negatif) diperoleh nilai precision sebesar 98,04\% dan recall sebesar 100\%, sedangkan dari 500 data opini diperoleh nilai precision sebesar 96,11\% dan recall p-ISSN:1693 - 2951; e-ISSN: 2503-2372 
sebesar 98,80\%. Untuk data sejumlah 1000 opini diperoleh recall sebesar 96,13\% dan precision sebesar 99,40\% . Dan dari 3300 data uji diperoleh nilai precission 97,21\%, nilai recall $96,01 \%$ dan akurasi sebesar $99 \%$.

\section{GRAFIK EKSPERIMEN}

Grafik eksperimen pada sistem opinion mining dengan svm linier biased dan linier unbiased. Grafik pada sistem ini terdiri dari hasil pengujian akurasi, precision dan recall. Masing masing hasil pengujian ditunjukkan pada di bawah ini

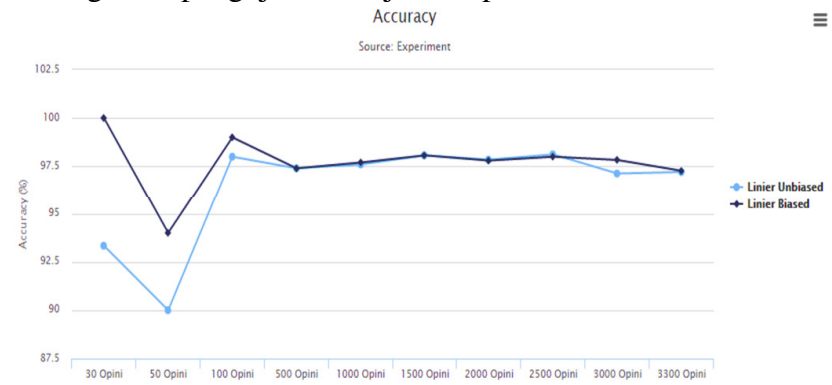

Gambar 7: Grafik Akurasi Pada Data Opini

Gambar 8 merupakan grafik hasil perhitungan akurasi dari linier biased dan linier unbiased. Dari beberapa data pengujian terlihat hasil akurasi dengan linier biased memiliki tingkat akurasi yang lebih tinggi dari linier unbiased.

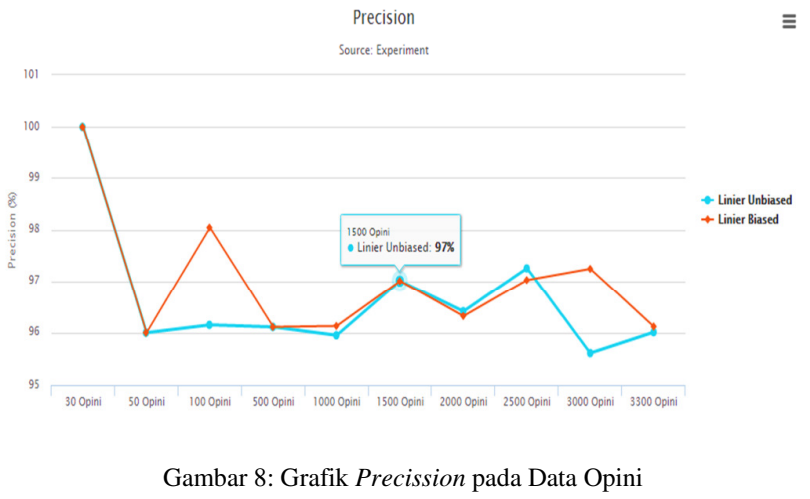

Gambar9menunjukkan grafik dengan precission. Berdasarkan pengujian precision, Secara keseluruhan padasvm linier biased tingkat precissionnya lebih tinggi dibandingkan tingkat precision linier unbiased.

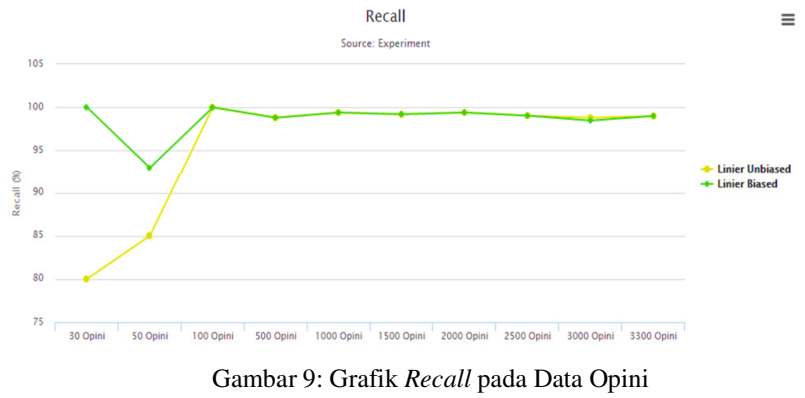

Pada gambar diatas pada grafik recall data uji opini terlihat SVM linier biased memiliki persentase rata rata recall yang lebih tinggi dibandingkan dengan SVM linier unbiased

\section{KESIMPULAN}

Penerapan SVM dengan menggunakan klasifikasi Linier yang terdiri dari linier bias dan linier unbiased. Pada percobaan dengan linier biased memiliki keakuratan hingga 100 persen. Presentase nilai Precision, recal dan akurasi pada penelitian opinion mining dengan metode pos tagging dan Support Vector Machine memiliki rata rata $89 \%$. Dengan demikian dapat dikatakan metode pos tagging dan Support Vector Machine mampu mengklasifikasikan kata kedalam opini dan menentukan kalimat ke dalam opini positif atau negatif

\section{UCAPAN TERIMA KASIH}

Terimakasih disampaikan kepada Prof. Ir. Ida Ayu Giriantari, Meng.Sc.,Ph.D dan Dr. Ir. Made Sudarma, M.A.Sc. selaku pembimbing pada penelitian ini. Terimakasih pada Ir IGAP Mahadewi,M.Kes selaku Kepala UPT JKMB Dinas Kesehatan Provinsi Baliatas ijin dan dukungannya untuk melakukan penelitian ini.

\section{REFERENSI}

[1] Tim UPT JKMB, "Pedoman Penyelenggaraan Jaminan Kesehatan Bali Mandara", Denpasar : Dinas Kesehatan Provinsi Bali, 2015.

[2] Bang Liu, "Sentiment Analysis and Subjectivity in Handbook of Natural Language Processing", 2010.

[3] Bo Pang and Lilian Lee, "Opinion Mining and Sentiment Analysis Foundations and Trends Information retrieval, vol - volume 2, no. issue 1- 2, pp. 1-135, 2008.

[4] Jurafsky, DS, "An Introduction to Natural Language Processing, Computational Linguistics and Speech Reconigtion", Pretince - Hall, Inc. New Jersey, 2000.

[5] Kathryn Widhiyanti, "Pos Tagging Bahasa Indonesia Hidden Markov Model dan Rule Based", 2012

[6] Pravesh Kumar Singh, Moh Shadid Husain, "Methodological Study of Opinion Mining and Sentiment Analysis Techiques", 2014

[7] AF Wicaksono, "HMM Based Part of Speech Tagger for Bahasa Indonesia", 2012

[8] Fam Rashel, Andry Luthfi, Arawinda Dinakaramani, "Building an Indonesian Rule Based Part of Speech Tagger", Universitas Indonesia, Depok, Indonesia.

[9] Wibisono Y, "Penggunaan Hidden Markov Model untuk Kompresi Kalimat", Program Magister Informatika, Institut Teknologi Bandung, 2008.

[10] M Rushdi Saleh, MT Martin - valdivia, A. Monrejo-Raez, L A Urena Lopez, "Expreiments with SVM to Classifify Opinion in Different Domain", 2011

[11] George Forman, "BNS Feature Scalling : An Improved Repsentation over TF IDF for SVM", 2008 